\title{
Screening of Pumpkin (Cucurbita moschata L.) Genotypes under Sodic Ecosystem
}

\author{
K. Kumanan ${ }^{1 *}$ and A. Nithya Devi ${ }^{2}$ \\ ${ }^{1}$ Vegetable Research Station, Palur, Cuddalore District, Tamil Nadu, India \\ ${ }^{2}$ Horticultural College and Research Institute for Women, Tiruchirappalli, India \\ *Corresponding author: kumanan@tnau.ac.in (ORCID ID: 0000-0002-6111-6918)
}

Paper No. 937

Received: 09-09-2021

Revised: $17-11-2021$

Accepted: 03-12-2021

\begin{abstract}
Sodicity is a major abiotic stress reducing the yield of a wide variety of crops all over the world. Soil sodicity is a significant crop production constraint around the world. Inherited tolerance is a precursor to pre-breeding and breeding tolerant cultivars. In order to investigate the antioxidant enzymes activity, 17 genotypes of pumpkin for sodicity tolerance studies were taken up at Horticultural College and Research Institute for Women, Tiruchirappalli using Randomized Block Design with three replications. The antioxidant enzyme system of plants plays an important role in the scavenging of Reactive Oxygen Species (ROS) that accumulate during stress and is the first line of defence to counter the deleterious stress effects. Proline content significantly increased in salt-tolerant genotypes under sodic soil condition. Catalase and peroxidase activity which plays a significant role in abiotic stress. Significantly decreased in salt-sensitive genotype while significantly increased in salt tolerant genotypes. The salt-tolerant genotype CM -11 (Madurai) maintained higher levels of chlorophyll $(3.7 \mathrm{mg} / \mathrm{g}$ ) and proline content

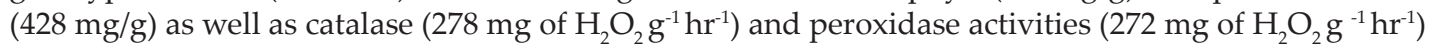
under sodic soil condition followed by CM -12 (Sedapatti) and CM-1 (Old Ayakkudi) which might be the mechanism responsible for sodicity tolerance. These germplasm accessions can be used in further breeding programme.
\end{abstract}

\section{HIGHLIGHTS}

( Soil sodicity is one of the major constraints for the success of afforestation worldwide. High sodicity causes poor soil physical conditions and thus adversely affect plant growth and yield.

0 Presence of genetic variation in plant species has tremendous potential to maintain high plant growth and yield under sodic soil. Hence, the present investigation is undertaken with a view to attempt on crop improvement in pumpkin under sodic soil having $8.5 \mathrm{pH}$ and $15 \mathrm{dS} / \mathrm{m}$ Exchangeable Sodium Percent.

Keywords: Pumpkin, abiotic stress, sodicity tolerance

In recent times, pumpkin has got industrial importance with the development of pulp powder as a nutraceutical supplement to Vitamin A requirement. Pumpkin is cheaper source of Vitamin A when compared to carrot which necessitates specific climatic requirement for its production and high productivity per unit area. In India, pumpkin occupies an area of 78,000 ha with an annual production of 1,714,000 MT (Anonymous, 2018). Pumpkin is considered as a vegetable of immense value because of its high carotene content and good keeping quality. It plays an important role against vitamin A deficiency which concerns more than 250 million children aged less than five around the world. Pumpkin can be grown in a wide range of soils. Certain genotypes can thrive

How to cite this article: Kumanan, K. and Devi, A.N. 2021. Screening of Pumpkin (Cucurbita moschata L.) Genotypes under Sodic Ecosystem. Int. J. Ag. Env. Biotech., 14(04): 501-504.

Source of Support: None; Conflict of Interest: None 
well in sodic soils also. Sodicity is an indicator of the amount of exchangeable $\mathrm{Na}$ to $\mathrm{Ca}$ and $\mathrm{Mg}$ in soil and a high sodicity suppresses plant growth due to Na toxicity and nutrient imbalance in plants as well as low availability of mineral nutrients in soil (Graifenberg et al. 1996). Sodicity is generally associated with poor soil structure. For successful use of water with high sodic levels, it is necessary to know the effects of sodicity on the development of the species to be used and its tolerance level to such adverse condition (De Souza et al. 2014). During the last two decades manyworkers utilized breeding as a tool for improvement of yield in pumpkin (Sirohi and Ghorui 1993) However, the genetic potential of this crop needs further exploitation to its nearest perfection. Most of the varieties and hybrids available in India are large sized fruits of $4-5 \mathrm{~kg}$ which is not much preferred by a small family or nuclear family of three to four members. Further, with increased number of nuclear families of recent scenario in India, people prefer to buy only medium sized whole fruits of pumpkin instead of cut pieces. Further, the small fruits can be easily packed and transported without damage. Hence, the crop improvement work has been taken up with the objective of identifying genotypes with high yield, quality and small fruit. Thus, the present investigation was undertaken with the objective to study the extent of variability among the genotypes for yield and quality under sodic soil condition at the Department of Vegetable Science, Horticulture College and Research Institute for Women, Tiruchirappalli to find out suitable pumpkin genotype for earliness, high yield and quality. About 17 pumpkin genotypes collected from various places were evaluated for different quantitative characters viz., days to first female and male flower appearance, node number for first female and male flower appearance and biochemical parameters viz., proline, chlorophyll, catalase and peroxidase content.

\section{MATERIALS AND METHODS}

The basic materials for the study included 17 genotypes of various landraces of pumpkin. The details of the genotypes are furnished below (Table 1). They were grown in the experiment field at the College Orchard, Horticultural College and Research Institute for women, Tiruchirappalli. The experiment was laid out in Randomised Block Design with two replications. The soil of the experimental field was sodic, having sandy loam texture, with a $\mathrm{pH}$ of 9.00, EC $0.94 \mathrm{dSm}^{-1}$ and ESP 21.76 per cent. Pits of $60 \mathrm{~cm}$ diameter and $30 \mathrm{~cm}$ depth were taken at a spacing of $2 \times 2 \mathrm{~m}$. Each replication consisting of three pits per genotype and five seeds were sown in each pit and watered regularly. After germination, among the five seedlings, two healthy seedlings were retained in each pit and the rest were thinned out. The required cultural operations were followed as per the package of practices recommended for pumpkin. Five randomly selected plants were tagged in each genotype in each replication and biometric observations and physiological observations were recorded. The mean value of the five plants in each genotype in each replication was utilized for statistical analysis. The data recorded were statistically analysed and the conclusions were drawn.

Table 1: Details of pumpkin genotypes used in the study

\begin{tabular}{ll}
\hline Accession & Source \\
\hline $\mathrm{CM}-1$ & OldAyakkudi \\
$\mathrm{CM}-2$ & Kodumudi \\
$\mathrm{CM}-3$ & Vellore \\
$\mathrm{CM}-4$ & Satur \\
$\mathrm{CM}-5$ & Harur, Dharmapuri \\
$\mathrm{CM}-6$ & Tholudur \\
$\mathrm{CM}-7$ & Madurai \\
$\mathrm{CM}-8$ & Madurai \\
$\mathrm{CM}-9$ & Madurai \\
$\mathrm{CM}-10$ & Madurai \\
$\mathrm{CM}-11$ & Madurai \\
$\mathrm{CM}-12$ & Sedapatti \\
$\mathrm{CM}-13$ & Madurai \\
$\mathrm{CM}-14$ & Madurai \\
$\mathrm{CM}-15$ & Natham \\
$\mathrm{CM}-16$ & Madurai \\
$\mathrm{CM}-17$ & Madurai \\
\hline
\end{tabular}

\section{RESULTS AND DISCUSSION}

Earliness is an advantageous character for selecting breeding lines of commercial importance. It could be evaluated from the character viz., node number of first female and male flower production and days to first female flower and male flower opening. As 
Table 2: Effect of sodicity on growth parameters of pumpkin genotypes

\begin{tabular}{lllll}
\hline Genotypes & $\begin{array}{l}\text { Days to First Male } \\
\text { Flower Appearance }\end{array}$ & $\begin{array}{l}\text { Days to First Female } \\
\text { Flower Appearance }\end{array}$ & $\begin{array}{l}\text { Node Number of } \\
\text { First Male Flower } \\
\text { production }\end{array}$ & $\begin{array}{l}\text { Node Number of } \\
\text { First Female Flower } \\
\text { production }\end{array}$ \\
\hline $\mathrm{CM}-1$ & 44.33 & 58.00 & 8.50 & 16.83 \\
$\mathrm{CM}-2$ & 51.00 & 63.33 & 9.83 & 19.33 \\
$\mathrm{CM}-3$ & 44.67 & 59.67 & 9.50 & 18.33 \\
$\mathrm{CM}-4$ & 45.33 & 61.17 & 10.67 & 19.33 \\
$\mathrm{CM}-5$ & 44.67 & 60.33 & 12.67 & 21.83 \\
$\mathrm{CM}-6$ & 44.67 & 61.33 & 10.33 & 19.33 \\
$\mathrm{CM}-7$ & 51.33 & 66.67 & 12.00 & 20.17 \\
$\mathrm{CM}-8$ & 53.00 & 64.00 & 10.33 & 20.17 \\
$\mathrm{CM}-9$ & 52.00 & 66.83 & 7.83 & 16.50 \\
$\mathrm{CM}-10$ & 51.17 & 63.50 & 7.17 & 16.50 \\
$\mathrm{CM}-11$ & 43.00 & 55.83 & 10.50 & 20.67 \\
$\mathrm{CM}-12$ & 42.50 & 56.00 & 8.83 & 18.67 \\
$\mathrm{CM}-13$ & 50.67 & 66.00 & 7.50 & 16.83 \\
$\mathrm{CM}-14$ & 51.00 & 65.17 & 10.17 & 18.00 \\
$\mathrm{CM}-15$ & 50.83 & 64.00 & 8.50 & 17.83 \\
$\mathrm{CM}-16$ & 47.17 & 56.50 & 9.17 & 17.83 \\
$\mathrm{CM}-17$ & 49.50 & 64.17 & 11.17 & 19.17 \\
\hline $\mathrm{Grand} \mathrm{Mean}$ & 47.8238 & 58.5003 & 9.1874 & 18.0594 \\
\hline $\mathrm{SEd}$ & 0.4929 & 1.0758 & 0.5537 & 3.4421 \\
\hline $\mathrm{CD}(0.5 \%)$ & 1.0450 & 2.2806 & 1.1739 & 7.2971 \\
\hline
\end{tabular}

revealed from mean data, among the 17 genotypes, CM -10 recorded the first female flower in earlier node of 16.5, followed by CM -9(16.51) and CM -1 (16.83). The genotype CM -12 recorded the earliest male flowering at 42.50 days (Table 2). Earliness is considered as one of the most important character in any crop improvement programme, and most of the genotypes or accessions are preferred in crop improvement programme when higher yield is coupled with earliness. The present study also brought out certain genotypes with significant earliness with respect to days to first male and female flower opening. Early opening of both male and female flower reduces the crop duration. Similar results was reported by Tamilselvi and Jansirani (2017) in pumpkin. The genotype CM -11 recorded the earliest female flowering (55.83 days) followed by CM -12 (56 days) and late flowering was observed in CM-9 at 66.83 days.

Total chlorophyll content influences the photosynthetic rate and thereby the efficiency of the plants in assimilates production. Hence, measurement of total chlorophyll content indirectly indicates the efficiency of the photosynthesis and photosynthates production. The total chlorophyll content was reduced with levels of sodicity. Higher total chlorophyll content was recorded in $\mathrm{CM}-11$ $(3.7 \mu \mathrm{g} / \mathrm{g})$ followed by $\mathrm{CM}-1(3.5 \mu \mathrm{g} / \mathrm{g})$. On the other hand, tolerant genotypes protected their chlorophyll content (Sevengor et al. 2011; Yasar et al. 2006). Under stress conditions, functions of proline include osmotic adjustment, protection of enzymes and membranes and also acts as a reservoir of energy and nitrogen for utilization during exposure to salt stress. In the present study, proline content of pumpkin genotypes exhibited an increasing trend with levels of sodicity. The genotype CM -11 recorded the highest proline content $(428 \mathrm{mg} / \mathrm{g})$ followed by CM $-12(422 \mathrm{mg} / \mathrm{g})$. As discussed above, the proline has taken a protective role against osmotic dehydration and hence the CM-11 seem to be tolerant to sodicity. Effects of sodicity stress progressively increased the proline content in pumpkin cultivars (Gilbert et al. 1998; Sun and Luo, 2013). The genotype CM - 12 recorded the highest peroxidase content of $272 \mu \mathrm{g}$ of $\mathrm{H}_{2} \mathrm{O}_{2} \mathrm{~g}^{-1}$ $\mathrm{hr}^{-1}$ followed by CM -11 (270.5 $\mu$ g of $\left.\mathrm{H}_{2} \mathrm{O}_{2} \mathrm{~g}^{-1} \mathrm{hr}^{-1}\right)$. The genotype $\mathrm{CM}-11$ recorded the highest catalase 
Table 3: Mineral content and enzyme activity of different pumpkin genotypes

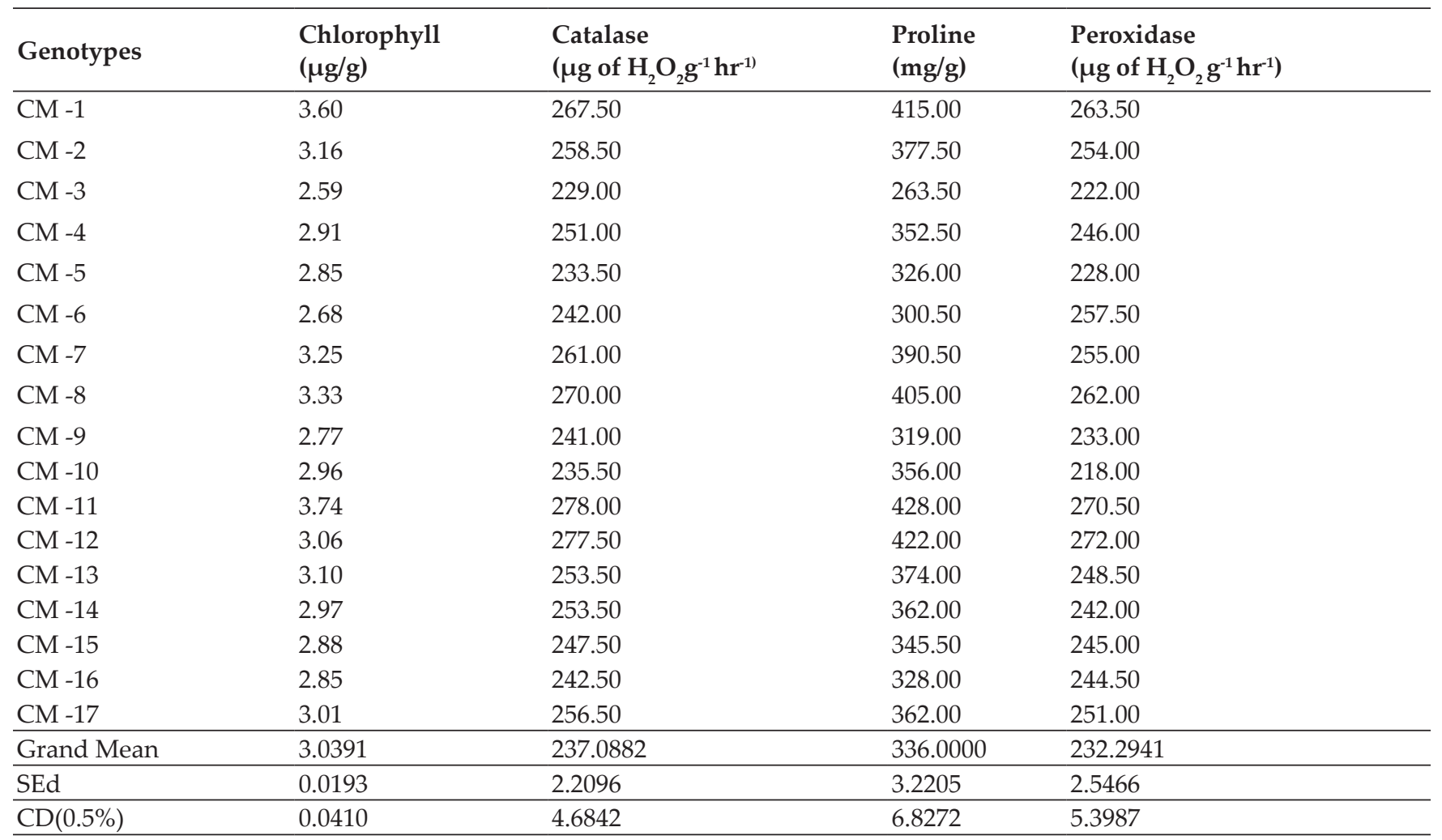

content $\left(278 \mu \mathrm{g}\right.$ of $\left.\mathrm{H}_{2} \mathrm{O}_{2} \mathrm{~g}^{-1} \mathrm{hr}^{-1}\right)$ followed by $\mathrm{CM}$ $-12\left(277.5 \mu \mathrm{g}\right.$ of $\left.\mathrm{H}_{2} \mathrm{O}_{2} \mathrm{~g}^{-1} \mathrm{hr}^{-1}\right)$ and less amount of catalase content was observed in CM -3 with $229 \mu \mathrm{g}$ of $\mathrm{H}_{2} \mathrm{O}_{2} \mathrm{~g}^{-1} \mathrm{hr}^{-1}$ (Table 3). The activities of catalase and peroxidase in the pumpkin cultivars increased significantly under sodicity stress, which suggested that the antioxidant defense system of the pumpkin cultivars was enhanced rapidly to scavenge all ROS generated by sodicity stress (Sun and Luo 2013). These enzymes were also reported to be important in sodicity tolerance in melon (Kusvuran et al. 2007; Yasar et al. 2006).

\section{REFERENCES}

Anonymous, 2018. National Horticulture Board. Area and production Statistics. Advance estimate of area and production of horticulture crops (2017-2018). https:// agricoop.nic.in/sites/default/files/Horticulture \%20 Statistics\%20at\%20a\%20Glance-2018.pdf Last Accessed on $8^{\text {th }}$ March,2021

De Souza, E.R., Dos Santos Freire, M.B.G., De Melo, D.V. M.and De Assunção Montenegro, A.A. 2014. Management of Atriplex nummularia Lindl. in a salt affected soil in a semi arid region of Brazil. Int. J. Phytoremediation, 16(1): 73-85.

Gilbert, G.A., Gadush, M.V., Wilson, C. and Madore, M.A. 1998. Amino acid accumulation in sink and source tissues of Coleus blumei Benth. during salinity stress. J. Exp. Bot., 49(318): 107-114.

Graifenberg, A., Botrini, L., Giustiniani, L. and Lipucci Di Paola, M. 1996. Yield, growth and element content of zucchini squash grown under saline-sodic conditions. Int. J. Hortic. Sci., 71(2): 305-311.

Kusvuran, S., Ellialtioglu, S., Yasar, F. and Abak, K. 2007. Effects of salt stress on ion accumulation and activity of some antioxidant enzymes in melon (Cucumis melo L.). J. Food Agric. Environ., 5(2): 351.

Sevengor, S., Yasar, F., Kusvuran, S. and Ellialtioglu, S. 2011. The effect of salt stress on growth, chlorophyll content, lipid peroxidation and antioxidative enzymes of pumpkin seedling. Afr. J. Agric. Res., 6(21): 4920-4924.

Sirohi, P. and Ghorui, S. 1993. Gene effects of certain quantitative characters in pumpkin. Veg. Sci., 20(2): 158162.

Sun, Y.D. and Luo, W.R. 2013. Effects of NaHCO3 stress on the growth and physiological indexes of pumpkin seedlings. Adv. J. Food Sci. Technol., 5: 1641-1645.

Tamilselvi, N. and Jansirani, P. 2017. Evaluation of Pumpkin (Cucurbita moschata L.) Genotypes for Earliness, Yield and Quality. Int. J. Curr. Microbiol. App. Sci., 6(3): 1554- 1559.

Yasar, F., Kusvuran, S. and Ellialtioglu, S. 2006. Determination of anti-oxidant activities in some melon (Cucumis melo L.) varieties and cultivars under salt stress. Hortic. Sci. Biotechnol., 81(4): 627-630. 